\title{
Interferon- $\gamma$ Inhibits DNA Synthesis and Insulin-Like Growth Factor-II Expression in Human Neuroblastoma Cells
}

\author{
D.M. Martin, R.O. Carlson, and E.L. Feldman \\ Department of Neurology and the Neuroscience Program (D.M.M., E.L.F.) and Department of Biochemistry \\ (R.O.C.), The University of Michigan, Ann Arbor, Michigan
}

Interferon- $\boldsymbol{\gamma}($ IFN- $\boldsymbol{\gamma})$ is known to be an antiproliferative, differentiating agent in many cell types, including neuroblastoma. In this study, we determined the effects of IFN- $\boldsymbol{\gamma}$ on cellular growth and expression of insulin-like growth factor II (IGF-II) and IGF receptors in the human neuroblastoma cell line SH-SY5Y. Incubation of SH-SY5Y cells in IFN- $\gamma(\mathbf{2 0 - 1 0 0 ~ U / m l )}$ induced the formation of long neuritic processes. IFN- $\gamma$ treatment also induced decreases in $\left[{ }^{3} \mathrm{H}\right] \mathrm{TdR}$ incorporation, as well as serum-dependent changes in cell number. Treatment with IFN- $\boldsymbol{\gamma}$ reduced cell number $33 \%$ in the presence of serum but had no effect on cell number in the absence of serum. IGF-II mRNA content was $60 \%$ inhibited by IFN- $\gamma$, and was not serum dependent. The concentration of immunoreactive IGF-II in SH-SY5Y conditioned medium was also reduced in the presence of IFN- $\gamma$, to less than half of control levels. In contrast, type I IGF receptor mRNA content was increased more than three-fold after treatment with IFN- $\gamma$ and serum. Co-incubation in IFN- $\gamma(20-100 \mathrm{U} / \mathrm{ml})$ and IGF-II $(3-10 \mathrm{nM})$ prevented the inhibitory effects of IFN- $\gamma$ on $\left[{ }^{3} \mathrm{H}\right] \mathrm{TdR}$ incorporation in serum-free media. Our results suggest that IFN- $\boldsymbol{y}$ may inhibit DNA synthesis and cell growth by interfering with an IGF-II/type I IGF receptor autocrine growth or survival mechanism.

Key words: mRNA, serum, cell cycle, mitogens, proliferation

\section{INTRODUCTION}

Gene expression is known to be influenced by the presence of extracellular factors which inhibit or stimulate cellular growth (Rozengurt, 1986). Interferon- $\gamma$ (IFN- $\gamma$ ), a member of the interferon family of cytokines which is used clinically as an antitumor agent, inhibits cellular proliferation and induces differentiation in a wide variety of cell types, including neuroblastoma (Watanabe et al., 1989; Parodi et al., 1989). IFN- $\gamma$, also known as type II interferon, is produced by mitogenic stimulation of $\mathrm{T}$ lymphocytes and interacts with specific receptors which have been shown to be present on most mammalian cell types (Borden, 1992). The mechanism of growth inhibition by interferons is thought to include regulation of expression of cell surface antigens, intracellular enzymes, and oncogenes (Borden, 1992). Interferons can also prolong all phases of the cell cycle and antagonize the mitogenic effects of platelet-derived growth factor (PDGF), fibroblast growth factor (FGF), epidermal growth factor (EGF), and insulin (Creasey et al., 1980; Balkwill and Taylor-Papadimitriou, 1978; Lin et al., 1986; Heyns et al., 1985; Shearer and TaylorPapadimitriou, 1987). Collectively, these observations implicate IFN- $\gamma$ as a general antiproliferative agent which can interact with and potentially regulate other growth factors.

IGF-II is a member of the insulin family of mitogenic peptides which also includes insulin, IGF-I, and relaxin (Blundell and Humbel, 1980; DiCicco-Bloom and Black, 1988). Many fetal cell types and neuroblastoma tissues synthesize and secrete IGF-II and divide in response to it, suggesting IGF-II can act as an autocrine mitogen during development and tumorigenesis (Lee et al., 1990; Drago et al., 1991; Rappolee et al., 1992; El-Badry et al., 1989). The human neuroblastoma cell line, SH-SY5Y (Biedler et al., 1978), expresses high levels of mRNA for IGF-II and IGF receptors (Martin et al., 1992), and also exhibits functional IGF-II binding sites (Mattsson et al., 1990; Recio-Pinto and Ishii, 1988). SH-SY5Y cells respond to IGF-II with increased DNA synthesis and neuritic outgrowth (Recio-Pinto et al., 1986; Feldman and Randolph, 1991; Recio-Pinto

Received August 12, 1992; revised November 2, 1992; accepted November 3, 1992.

Address reprint requests to E.L. Feldman, M.D., Ph.D., 1120C Neuroscience Laboratory, 1103 E. Huron Ave., Ann Arbor, MI 48104.

Present address of R.O. Carlson: Georgetown University Medical Center, Department of Biochemistry and Molecular Biology, 3900 Reservoir Rd., Washington, DC 20007. 
and Ishii, 1988), and can survive in serum-free media (Sonnenfeld and Ishii, 1982). These observations are consistent with an IGF-II-mediated autocrine growth or survival mechanism in SH-SY5Y cells.

IGF-II exerts most of its effects on cell growth via interaction with the type I and type II IGF receptors (Roth, 1988). The type I IGF receptor is an $\alpha-\beta-\beta-\alpha$ tetramer, structurally similar to the insulin receptor, which also has an intracellular tyrosine kinase domain (Morgan et al., 1986). The type I IGF receptor binds IGF-I with the highest affinity, but also binds IGF-II and insulin with lower affinity (Steele-Perkins et al., 1988). The type II IGF receptor is comprised of a single transmembrane spanning protein, identical to the cation-independent mannose-6 phosphate (Man-6 P) receptor (Morgan et al., 1987) which targets intracellular hydrolytic enzymes from the Golgi apparatus to lysosomes (Nielsen et al., 1991). The type II IGF receptor binds IGF-II with the highest affinity, binds IGF-I with lower affinity and does not bind insulin (Roth, 1988).

In the current study, we tested the effects of IFN- $\gamma$ on cellular growth and expression of IGF-II and IGF receptors in SH-SY5Y cells. We found that IFN- $\gamma$ induced the formation of long neuritic processes, inhibited DNA synthesis, and, in the presence of serum, decreased cellular proliferation. IFN- $\gamma$ also inhibited IGF-II mRNA and immunoreactive IGF-II, but increased type I IGF receptor mRNA. Exogenous addition of IGF-II prevented the IFN- $\gamma$ induced inhibition of DNA synthesis, in the absence of serum. Taken together, these results indicate that factors in serum, including IGF-II, can modulate the effects of IFN- $\gamma$ on cellular growth and that IFN- $\gamma$ may inhibit cellular growth by disrupting an IGFII/type I IGF receptor-mediated autocrine growth or survival mechanism.

\section{MATERIALS AND METHODS}

\section{Materials}

Tissue culture flasks were purchased from Corning Glass Works (Corning, NY) and Costar (Cambridge, MA). Human recombinant IFN- $\gamma$ was purchased from Boehringer Mannheim Biochemicals, Indianapolis, IN (Cat. no. 1050-494, 99\% pure, as determined by HPLC, with endotoxin (LAL) $<10 \mathrm{EU} / \mathrm{mg}$ ). The IFN- $\gamma$ was diluted in sterile Dulbecco's modified Eagle's medium $(\mathrm{DME})$ and stored at $-20^{\circ} \mathrm{C}$. Restriction enzymes were obtained from Boehringer Mannheim and Gibco BRL (Gaithersburg, MD). [ $\left.{ }^{32} \mathrm{P}\right] \mathrm{dCTP}$ was purchased from NEN Dupont (Boston, MA). Recombinant human IGF-II from Bachem (Torrance, CA) or Biosource International (Westlake Village, CA) was stored at $-70^{\circ} \mathrm{C}$ in $0.01 \mathrm{M}$ acetic acid. Unless indicated, all other chemicals were from Sigma Chemical Company (St. Louis, MO).

\section{Cell Culture}

SH-SY5Y human neuroblastoma cells (Biedler et al., 1978) were kindly provided by Dr. Stephen Fisher, University of Michigan Medical Center. SH-SY5Y cells were cultured in DME and $10 \%$ calf serum $(\mathrm{CS})$ at $37^{\circ} \mathrm{C}$ in a humidified atmosphere containing $10 \% \mathrm{CO}_{2}$.

\section{Analysis of Cell Morphology}

To study SH-SY5Y morphology, cells were plated $\left(2 \times 10^{4}\right.$ cells per T25 flask) in DME $+10 \%$ CS. After 2 days, cells were washed twice with DME and fresh DME $\pm 10 \%$ CS with $0,20,50$, or $100 \mathrm{U} / \mathrm{ml} \mathrm{IFN}-\gamma$ was added. Phase-contrast photomicrographs were taken on a Leitz Fluovert microscope (Wetzlar, Germany). After printing, the final magnifications were $120 \times$ and $240 \times$.

\section{DNA Synthesis and Cell Proliferation Assays}

To determine the level of DNA synthesis, SHSY5Y cells were plated in 6-wells $\left(2.3 \times 10^{5}\right.$ cells per $3.5-\mathrm{cm}$-diameter well) in DME $+10 \% \mathrm{CS}$ and allowed to grow for 3 days. Medium was then removed, cells were rinsed twice with DME, and DME $\pm 10 \% \mathrm{CS}$ and $\pm \operatorname{IFN}-\gamma(0,20,50$, or $100 \mathrm{U} / \mathrm{ml})$ and \pm IGF-II $(10 \mathrm{nM})$ was added. For measurement of DNA synthesis, $\left[{ }^{3} \mathrm{H}\right] \mathrm{TdR}\left(\left[\right.\right.$ methyl $\left.-{ }^{3} \mathrm{H}\right]$ thymidine, $6 \mu \mathrm{Ci}, 6,700 \mathrm{Ci} / \mathrm{mol}$, NEN DuPont, Boston, MA) was pipetted into each well and cells were incubated for $2 \mathrm{hr}$ at $37^{\circ} \mathrm{C}$. Cells were washed twice with ice-cold PBS and four times with ice-cold 5\% trichloroacetic acid (TCA). One milliliter of $0.1 \% \mathrm{SDS} / 0.1 \mathrm{~N} \mathrm{NaOH}$ was added for a 1-hr incubation at $37^{\circ} \mathrm{C}$. A $0.5-\mathrm{ml}$ aliquot of the TCA-insoluble radioactivity was measured by liquid scintillation counting on a 2,000CA scintillation counter (Packard, Downers Grove, IL). The number of viable cells was determined from parallel wells of SH-SY5Y cells by trypan blue dye exclusion, as previously described (Feldman and Randolph, 1991).

\section{Northern Analysis and cDNA Probes}

For Northern analysis, SH-SY5Y cells were plated $\left(1.8 \times 10^{6}\right.$ cells per T75 flask) in DME $+10 \% \mathrm{CS}$ and maintained in culture for 7-8 days. The medium was then removed, cells were rinsed twice in DME, and DME \pm $10 \% \mathrm{CS}$ and IFN- $\gamma(0,20,50$, or $100 \mathrm{U} / \mathrm{ml})$ was added. RNA was extracted 3 days after addition of IFN $-\gamma$ by the method of Chomczynski and Sacchi (1987). Northern analysis was performed essentially as previously described (Martin et al., 1991), using [ $\left.{ }^{32} \mathrm{P}\right] \mathrm{dCT}$-labeled cDNA probes $\left(0.1-10 \times 10^{8} \mathrm{cpm} / \mu \mathrm{g}\right)$ for IGF-II (bases 1-854 of a cDNA encoding exons 7,8 , and part of 9 was excised with PstI) (Bell et al., 1984), type I IGF receptor 
(bases 1490-2737 encoding the $\alpha$ and chains was excised with Eco RI and HindIII) (Ullrich et al., 1986), and type II IGF receptor (the complete $9.1 \mathrm{~kb}$ cDNA was excised with Sall) (Oshima et al., 1988). A 1.8-kb Pstl$P$ stI fragment of a chicken $\beta$-actin cDNA was also used for hybridization analysis (Cleveland et al., 1980). Individual Nytran membranes containing total cellular RNA were hybridized successively by stripping and reprobing as described in the manufacturer's instructions (Schleicher and Schuell, Keene, NH). Autoradiographs from Northern analysis were scanned by densitometry, and relative OD were obtained by analyzing several exposures from each experiment and averaging values in the linear range of the film. These values were expressed as a percentage of the control lane and were then divided by the percentage of control values obtained similarly from $\beta$-actin hybridizations. We found that IFN- $\gamma$ did not significantly change steady-state mRNA levels for $\beta$-actin, and therefore used $\beta$-actin mRNA content as a control for the amount of RNA loaded onto the gel.

\section{IGF-II Protein Secretion Assay}

RIA was performed essentially as discussed by Cullen and colleagues (Cullen et al., 1991). Cells were plated $\left(1.8 \times 10^{6}\right.$ cells per T75 flask $)$ and maintained in culture for 7-8 days. Cells were washed twice with DME, then $10 \mathrm{ml}$ fresh DME and $0,20,50$, or $100 \mathrm{U} / \mathrm{ml}$ IFN- $\gamma$ was added. After 3 days, media were collected and centrifuged to remove any cellular debris. PMSF $(0.1 \mu \mathrm{g} / \mathrm{ml})$ and aprotinin $(2 \mu \mathrm{g} / \mathrm{ml})$ were added to inhibit protease activity. The media sample was then concentrated using Centriprep-3 concentrators (MW cut-off = 3,000 Da, Amicon, Beverly, MA), and acetic acid was added to a final concentration of $0.1 \mathrm{M}$ before storage at $-70^{\circ} \mathrm{C}$. As previously described, binding proteins were separated from the IGF by double extraction with Seppak $\mathrm{C}_{18}$ columns (Millipore, Bedford, MA) and assayed before and after column separation using an activated charcoal binding protein assay. Samples or IGF-II standards, 20,000-30,000 cpm ${ }^{125}$ I-labeled IGF-II (Amersham, Arlington Heights, IL), and $0.6 \mathrm{ng}$ of a rat monoclonal antibody against IGF-II (Upstate Biotechnologies, Inc., Lake Placid, NY) were incubated in $400 \mu$ RIA buffer (1\% BSA, $0.1 \mathrm{M} \mathrm{NaH}_{2} \mathrm{PO}_{4}$, pH 7.4, $0.02 \%$ sodium azide) overnight. Bound IGF-II antibody complex was precipitated with $100 \mu 15 \%$ human $\gamma$-globulin and $500 \mu \mathrm{l} 25 \%$ polyethylene glyco and counted in a $\gamma$ counter.

\section{RESULTS}

\section{Effects of IFN- $\gamma$ on Cell Morphology, DNA Synthesis, and Proliferation}

SH-SY5Y cell morphology was altered by serum and IFN- $\gamma$. As early as 2 days after a media change,
SH-SY5Y cells cultured in serum appeared larger and more clustered relative to cells grown in serum-free media, which appeared flatter and more spread out (compare Figs. $1 \mathrm{~A}$ and $\mathrm{B}$ to Figs. $1 \mathrm{E}$ and F). In the presence of serum, low doses of IFN- $\gamma(20-100 \mathrm{U} / \mathrm{ml})$ induced the formation of long varicose neuritic processes (Fig 1C and D). In serum-free media, cells exhibited short neuritic processes which were elaborated by IFN- $\gamma(20-100$ $\mathrm{U} / \mathrm{ml}$ ) (Figs. $1 \mathrm{G}$ and $\mathrm{H}$ ).

IFN- $\gamma$ also exhibited inhibitory effects on DNA synthesis in SH-SY5Y cells, both in the presence and absence of serum. In the presence of serum, a 3-day exposure to IFN- $\gamma(20-100 \mathrm{U} / \mathrm{ml})$ inhibited $\left[{ }^{3} \mathrm{H}\right] \mathrm{TdR}$ incorporation per cell by $30-33 \%$ (Fig. 2A). In serum-free media, $\left[{ }^{3} \mathrm{H}\right] \mathrm{TdR}$ incorporation per cell was significantly decreased by $63 \%$ after 3 days in $100 \mathrm{U} / \mathrm{ml}$ of IFN- $\gamma$ (Fig. 2A). Cell number data from the experiment shown in Figure 2A are presented in Figure 2B. In the presence of serum, IFN- $\gamma(20-100 \mathrm{U} / \mathrm{ml})$ reduced cell number $13-$ $39 \%$ relative to the CS control (Fig. 2B). The inhibitory effects of IFN- $\gamma$ on cell number were not associated with a reduction in cell viability. In serum-free media, IFN- $\gamma$ (20-100 U/ml) had no significant effect on cell number (Fig. 2B). Thus, a 3-day incubation in IFN- $\gamma$ inhibited DNA synthesis in the presence or absence of serum, but reduced cell number only when serum was present.

A time course analysis of the effects of IFN- $\gamma(100$ $\mathrm{U} / \mathrm{ml}$ ) on SH-SY5Y DNA synthesis and cell number is presented in Figure 3 . In the presence of serum, $\left[{ }^{3} \mathrm{H}\right] \mathrm{TdR}$ incorporation per cell was reduced $41 \%$ relative to the CS control after a 1-day treatment with IFN- $\gamma$, and remained lower than control levels at each subsequent time point throughout the 4-day incubation period (Fig. 3A). In serum-free media, $\left[{ }^{3} \mathrm{H}\right] \mathrm{TdR}$ incorporation per cell was reduced $28 \%$ relative to the serum-free media control after one day in IFN- $\gamma$, and remained lower thereafter (Fig. 3B). The effects of serum and IFN- $\gamma$ on cell number followed the time course shown in Figure 3C. In serum alone, cell number steadily rose and, by 4 days, there was a 7 -fold increase in cell number above the day 0 serum-free control value. Addition of IFN- $\gamma$ to serum containing media significantly reduced cell number relative to the serum controls at each time point. In contrast to the inhibitory effects of IFN- $\gamma$ on cell number in the presence of serum, IFN- $\gamma$ had no significant effect on cell number in serum-free media over the entire 4-day incubation period.

\section{Effects of IFN- $\boldsymbol{\gamma}$ on IGF-II Expression}

To determine whether IFN- $\gamma$ altered IGF-II production in SH-SY5Y cells, we assayed IGF-II protein levels by RIA in serum-free conditioned media only, and not in serum-supplemented media, which contains IGF-II (Enberg and Hall, 1984). We detected immunoreactive IGF- 

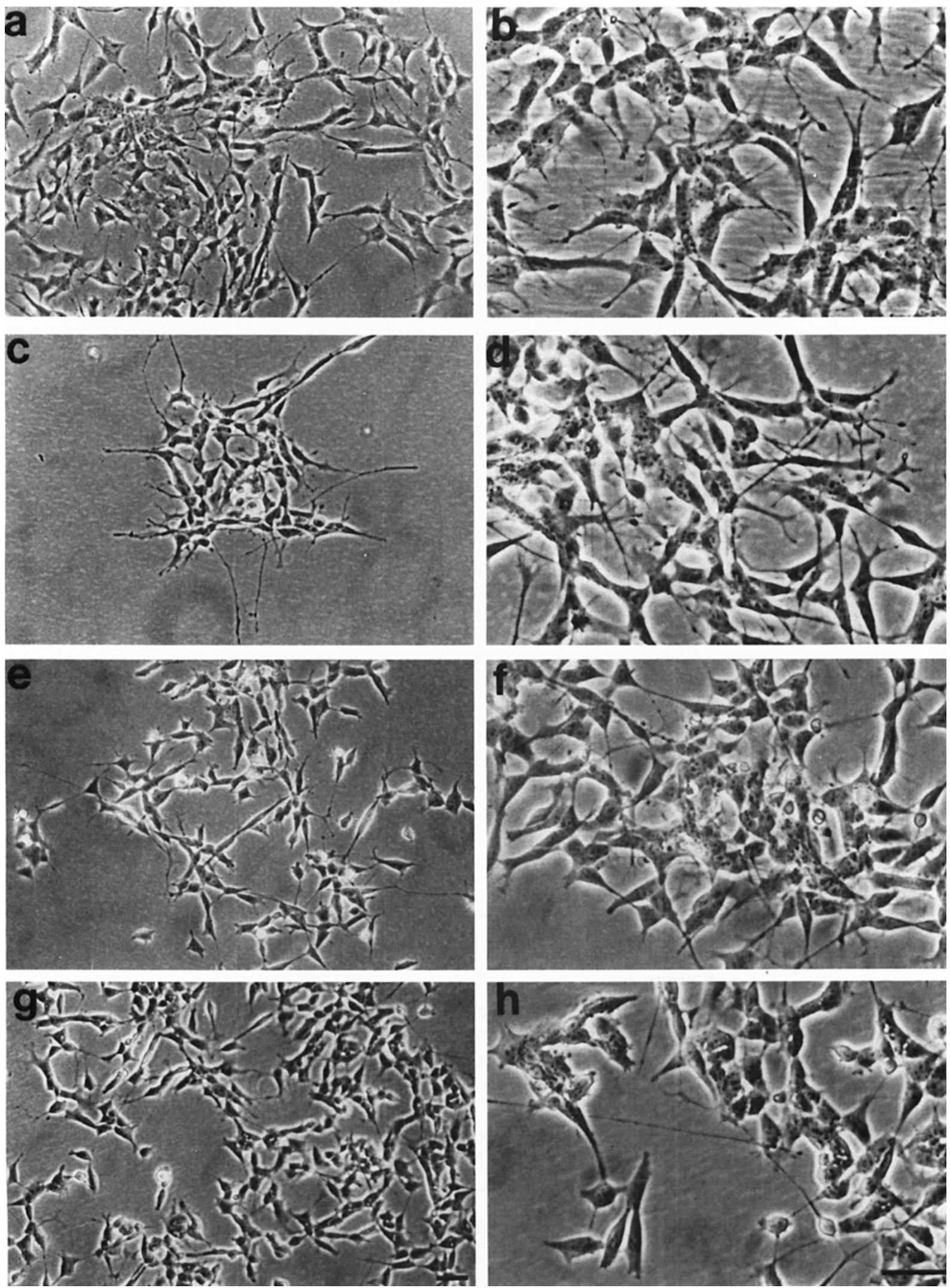

Fig. 1. Phase-contrast micrographs of SH-SY5Y cells cultured for four days in DME $+10 \%$ CS (a,b), DME $+10 \% \mathrm{CS}+20 \mathrm{U} / \mathrm{ml} \mathrm{IFN-} \boldsymbol{\gamma}(\mathbf{c}, \mathbf{d})$, DME $(\mathbf{e}, \mathbf{f})$, or DME $+20 \mathrm{U} / \mathrm{ml} \mathrm{IFN-} \gamma$ $(\mathbf{g , h})$ taken at low $(\mathbf{a}, \mathbf{c}, \mathbf{e}, \mathbf{g})$ and high $(\mathbf{b}, \mathbf{d}, \mathbf{f}, \mathbf{h})$ magnification. Bars are $50 \mu \mathrm{m}$. 

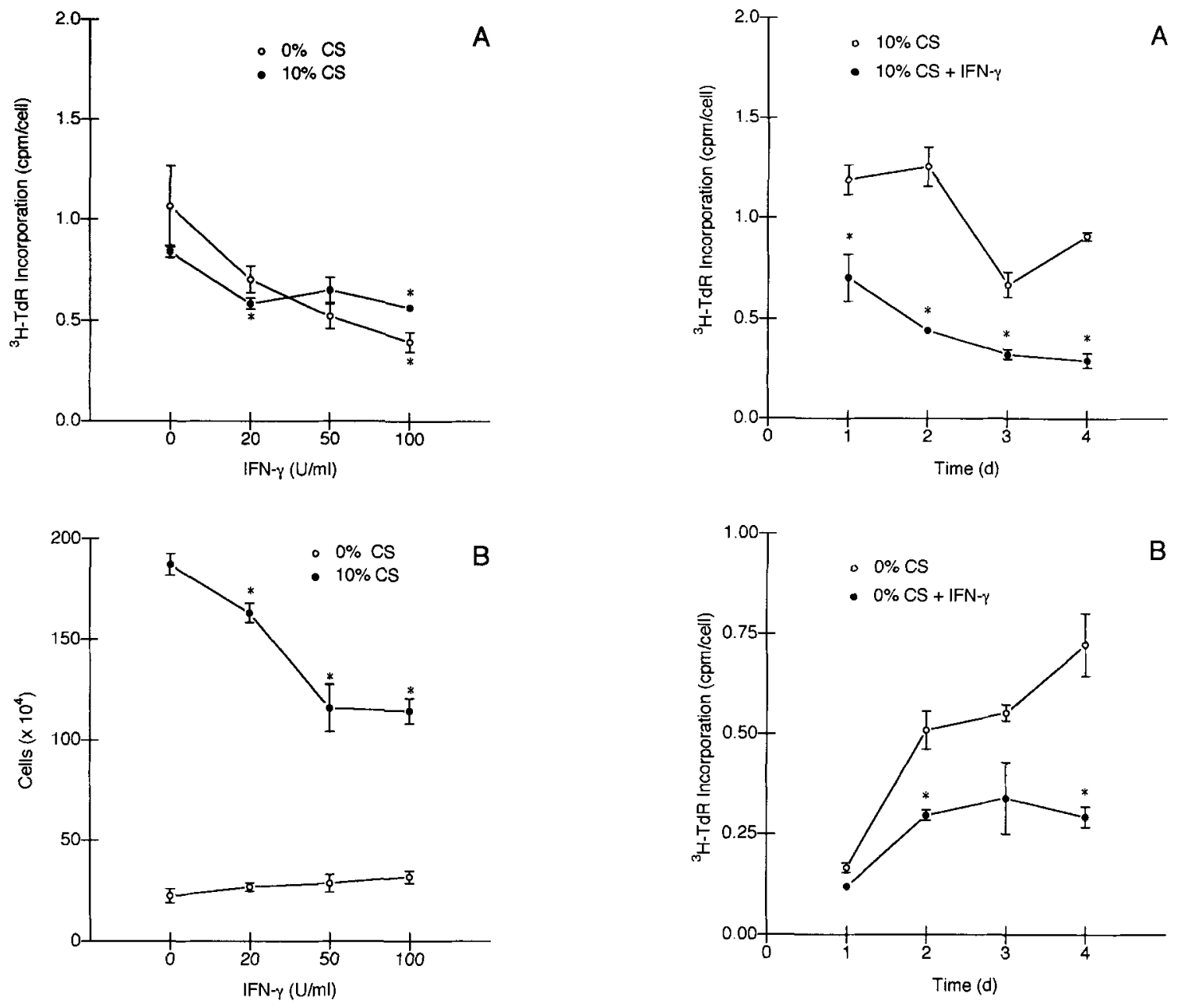

Fig. 2. Dose-response of IFN- $\gamma$ effects on $\left[{ }^{3} \mathrm{H}\right] \mathrm{TdR}$ incorporation (A) and cell number (B) in SH-SY5Y cells. $\left[{ }^{3} \mathrm{H}\right] \mathrm{TdR}$ and cell number from parallel wells were measured after a 3-day exposure to DME + 0\% CS $(0)$ or $10 \% \operatorname{CS}(\bullet)$ and IFN- $\gamma(0$, $20,50$, or $100 \mathrm{U} / \mathrm{ml})$ as indicated on the $x$-axes. Values in (A), expressed as $\mathrm{cpm}$ per cell, are means of triplicate wells \pm SEM from the same experiment as in (B). Data in (B), expressed as cells $\times 10^{4}$, are the means \pm SEM of triplicate wells from a representative experiment performed three times. Viable cells in (B) were counted by trypan blue dye exclusion as reported (Feldman and Randolph, 1991). ${ }^{*} P<0.05$ compared to the $0 \%$ CS or $10 \%$ CS control by unpaired, two-tailed $t$ test.

Fig. 3. Time course of IFN- $\gamma$ effects on $\left[{ }^{3} H\right] T d R$ incorporation $(\mathbf{A}, \mathbf{B})$ and cell number $(\mathbf{C})$ in SH-SY5Y cells over a period of 4 days. $\left[{ }^{3} \mathrm{H}\right] \mathrm{TdR}$ and cell number from parallel wells were measured after a 3-day exposure to DME $\pm 10 \% \mathrm{CS} \pm \mathrm{IFN}-\gamma$ $(100 \mathrm{U} / \mathrm{ml})$, as indicated in the legends. Values in (A) and (B), expressed as cpm per cell, are means of triplicate wells \pm SEM

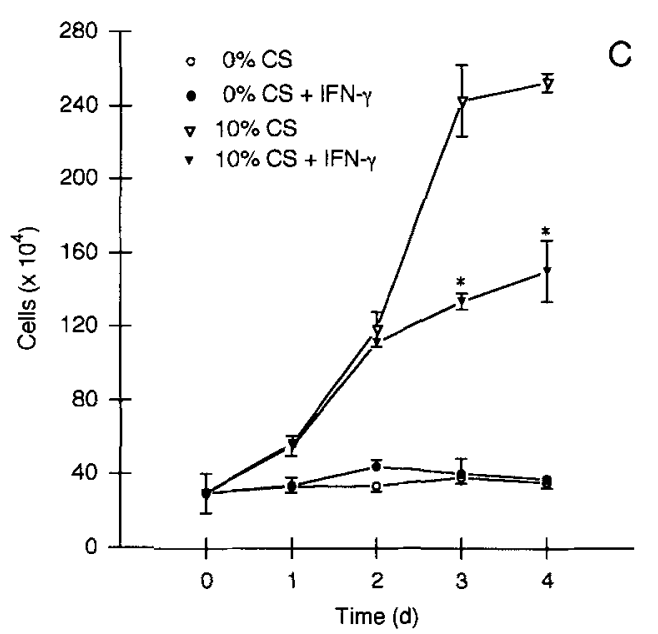

from a representative experiment performed four times. Data in (C), expressed as cells $\times 10^{4}$, are the means \pm SEM of triplicate wells from the same experiment as in $(\mathbf{A})$ and $(\mathbf{B})$. Viable cells in $(\mathbf{C})$ were counted by trypan blue dye exclusion. $* P$ $<0.05$ compared to the $0 \%$ CS or $10 \%$ CS controls for each time point by unpaired, two-tailed $t$ test. 


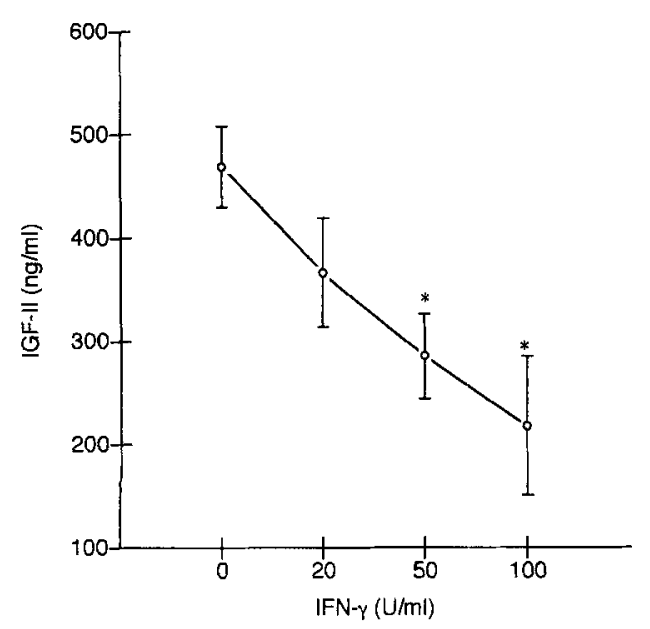

Fig. 4. RIA of IGF-II protein from SH-SY5Y cell conditioned media. Cells were incubated in DME $+\operatorname{IFN}-\gamma(0,20,50$, or $100 \mathrm{U} / \mathrm{ml}$ ), as indicated on $x$-axis, for 3 days. Media were then collected and concentrated, binding proteins removed, and IGF-II levels assayed. Values expressed as ng immunoreactive IGF-II per ml conditioned media are the means of two experiments \pm SEM. ${ }^{*} P<0.05$ compared to $0 \mathrm{U} / \mathrm{ml}$ IFN- $\gamma$ control by unpaired, two-tailed $t$ test.

II in serum-free media conditioned by SH-SY5Y cells for 3 days at a concentration of $469 \pm 39.0 \mathrm{ng} / \mathrm{ml}(63.4 \pm$ $5.3 \mathrm{nM})$. We observed a dose-dependent reduction in the amount of detectable immunoreactive IGF-II present after a 3-day incubation with IFN- $\gamma$ in serum-free media, to $285 \pm 41.5 \mathrm{ng} / \mathrm{ml}(38.5 \pm 5.6 \mathrm{nM})$ in $50 \mathrm{U} / \mathrm{ml}$ or 217 $\pm 67.4 \mathrm{ng} / \mathrm{ml}(29.3 \pm 9.1 \mathrm{nM})$ in $100 \mathrm{U} / \mathrm{ml}$ (Fig. 4). As described (Fig. 2B), there was no change in SH-SY5Y cell number with IFN- $\gamma$ treatment in serum-free media under similar plating conditions.

IFN- $\gamma$ also reduced IGF-II expression at the mRNA level. We detected three major IGF-II mRNA transcripts $(1.8,4.8,6.0 \mathrm{~kb})$ by Northern analysis of total RNA from SH-SY5Y cells (Fig. 5), as previously reported (Martin et al., 1992). We detected the 6.0-kb IGF-II mRNA transcript at higher levels than the $4.8-$ or $1.8-\mathrm{kb}$ transcripts, and therefore measured $6.0-\mathrm{kb}$ content as a representative value for IGF-II mRNA levels. In the presence of serum, a 3-day incubation of SH-SY5Y cells in 50 or $100 \mathrm{U} / \mathrm{ml} \mathrm{IFN- \gamma}$ induced $44 \%$ and $60 \%$ decreases in $6.0-\mathrm{kb}$ IGF-II mRNA content, respectively (Figs. 5 and 6). In serum-free media, 6.0-kb IGF-II mRNA content was inhibited $43 \%$ and $62 \%$ by 50 and $100 \mathrm{U} / \mathrm{ml}$ of IFN- $\gamma$, respectively (Figs. 5 and 6). The extent to which IFN- $\gamma$ reduced $6.0-\mathrm{kb}$ IGF-II mRNA content in serum or serum-free media was similar to the IFN- $\gamma$ induced reduction in IGF-II protein (compare Figs, 4 and 6).

\section{Effects of IFN- $\boldsymbol{\gamma}$ and IGF-II on DNA Synthesis}

Because (1) IFN- $\gamma$ inhibited DNA synthesis and IGF-II expression in this study and (2) IGF-II had previously been shown to stimulate DNA synthesis in SHSY5Y cells (Mattsson et al., 1986). We postulated that IFN- $\gamma$ may inhibit DNA synthesis by reducing the amount of IGF-II available. We therefore tested whether exogenous addition of IGF-II could prevent IFN- $\gamma$ inhibition of DNA synthesis. For these experiments, cells were treated for $24 \mathrm{hr}$, in the presence or absence of serum, with IGF-II $(3-10 \mathrm{nM})$, IFN- $\gamma(100 \mathrm{U} / \mathrm{ml})$, or both. In the presence of serum, IGF-II had no effect on $\left[{ }^{3} \mathrm{H}\right] \mathrm{TdR}$ incorporation per cell (Fig. 7A). In serum-free media, a 24-hr incubation in IGF-II increased $\left[{ }^{3} \mathrm{H}\right] \mathrm{T} d \mathrm{R}$ incorporation per cell 2.5 to 3.5 -fold above the serumfree control (Fig. 7B). IGF-II also appeared to prevent the inhibitory effects of IFN- $\gamma$ on DNA synthesis, but only in serum-free media. In the presence of serum, addition of IGF-II had no effect on IFN- $\gamma$ inhibition of DNA synthesis (Fig. 7A). In contrast, coincubation in IGF-II and IFN- $\gamma$ in serum-free media significantly increased $\left[{ }^{3} \mathrm{H}\right] \mathrm{TdR}$ incorporation per cell relative to cells treated with IFN- $\gamma$ alone (Fig. 7B).

\section{Effects of IFN- $\boldsymbol{\gamma}$ on IGF receptor mRNA}

By Northern analysis of total RNA, we detected an 11-kb type I IGF receptor mRNA transcript in SH-SY5Y cells, as previously described (Fig. 8A) (Martin et al., 1992). IFN- $\gamma$ regulated levels of type I IGF receptor mRNA, both in the presence and absence of serum. In the presence of serum, IFN- $\gamma$ induced increases in type I IGF receptor mRNA content, to $75 \%$ above the serum control in $20 \mathrm{U} / \mathrm{ml}$ and 3-fold above control in $100 \mathrm{U} / \mathrm{ml}$ (Fig. 8A and B). In serum-free media, IFN- $\gamma(100 \mathrm{U} / \mathrm{ml})$ increased levels of type I IGF receptor mRNA by $50 \%$ after a 3-day incubation, whereas lower doses of IFN- $\gamma$ had no significant effect on type I IGF receptor mRNA content (Fig. 8B). We also detected a 9.4-kb type II IGF receptor mRNA transcript by Northern analysis of total RNA from SH-SY5Y cells (Martin et al., 1992). Levels of this transcript were unchanged by IFN- $\gamma(20-100$ $\mathrm{U} / \mathrm{ml}$ ), both in the presence and absence of serum (Fig. 9).

\section{DISCUSSION}

Production of IGFs and their receptors in the nervous system (Bondy et al., 1992; Baskin et al., 1988), coupled with IGF modulation of fetal neuronal growth (Svrzic and Schubert, 1991; DiCicco-Bloom and Black, 1988), led us to speculate that expression of IGFs and IGF receptors may be regulated by factors which control neuronal growth. One such factor is IFN- $\gamma$, an antiviral, 


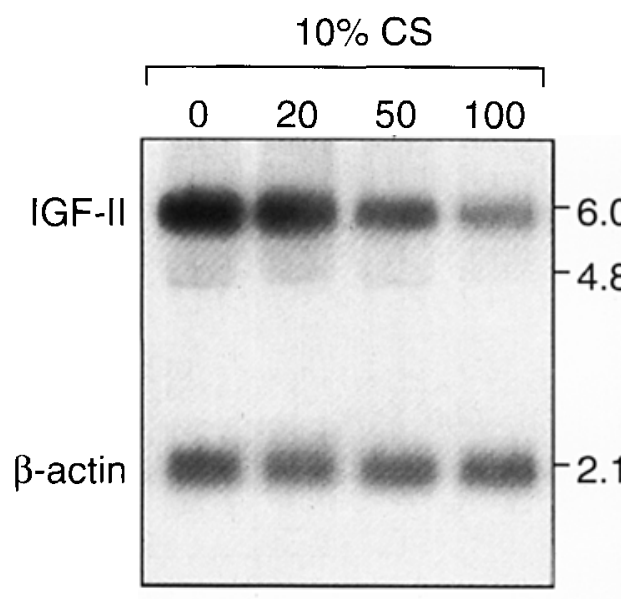

Fig. 5. Northern analysis of IGF-II mRNA. Cells were incubated for three days in DME $+\operatorname{IFN}-\gamma(0,20,50$, or $100 \mathrm{U} / \mathrm{ml})$ $+10 \% \mathrm{CS}$, as indicated above the lanes, and total RNA isolated. RNA (20 $\mu \mathrm{g}$ per lane) was loaded onto agarose gels, electrophoresed, and transferred to nylon membranes for successive hybridization with ${ }^{32} \mathrm{P}$-labeled cDNAs for IGF-II and

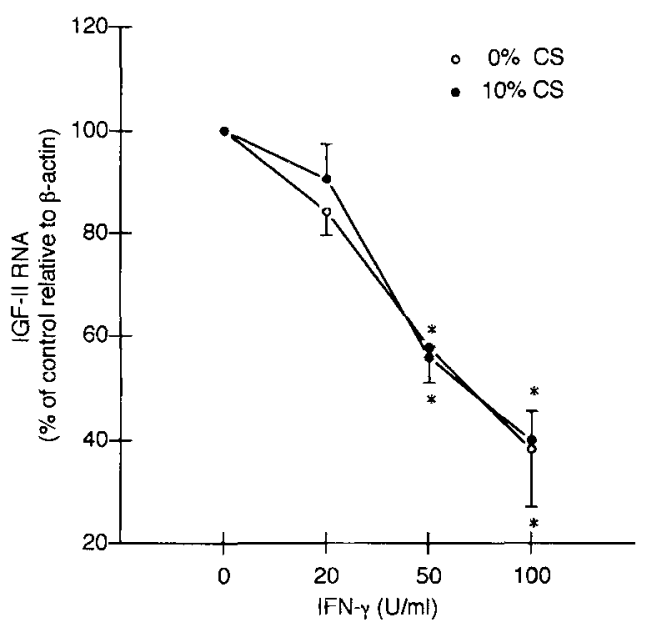

Fig. 6. Densitometric analysis of IGF-II mRNA. Autoradiographs from multiple exposures of the experiment shown in Figure 5 and an additional experiment were quantitated using relative OD as described in Materials and Methods. Values are means \pm SEM expressed as a percentage of control relative OD of the $6.0-\mathrm{kb}$ IGF-II mRNA transcript divided by relative OD of $\beta$-actin. ${ }^{*} P<0.05$ compared to $0 \% \mathrm{CS}(O)$ or $10 \% \mathrm{CS}$ (•) control by unpaired, two-tailed $t$ test.

antiproliferative agent produced by mitogenic stimulation of T lymphocytes (Borden, 1992). IFN- $\gamma$ inhibits DNA synthesis and promotes differentiation of many cell types, including neuroblastoma cells (Borden, 1992; Watanabe et al., 1989; Parodi et al., 1989; Ponzoni et al., 1992). The mitogenic activity of PDGF, EGF, or basic FGF on human fibroblasts (Howang, 1988; Oleszak, 1988 ) and vascular smooth muscle cells (Warner et al.,

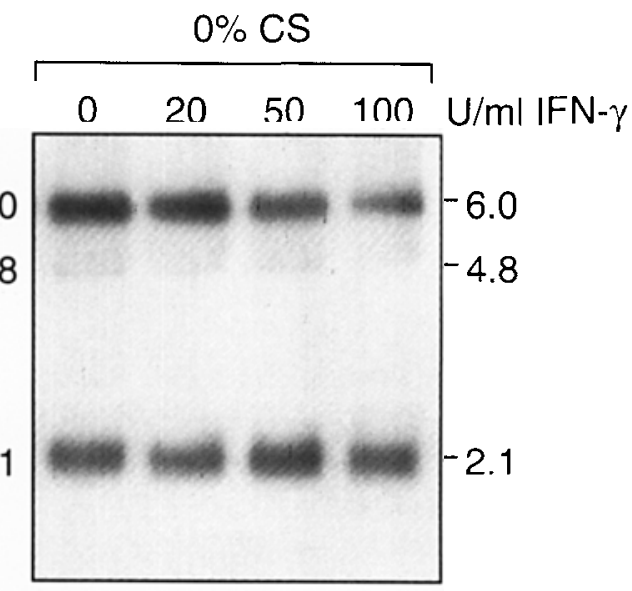

$\beta$-actin, as indicated. Amount of IFN- $\gamma$ in $\mathrm{U} / \mathrm{ml}$ is indicated above each lane. mRNA transcript sizes are shown at the right of each autoradiogram in $\mathrm{kb}$. Autoradiographs exposed $3 \mathrm{hr}$ (IGF-II/0\% CS), $24 \mathrm{hr}$ ( $\beta$-actin/0\% CS), $1.5 \mathrm{hr}$ (IGF-II/10\% $\mathrm{CS})$, and $24 \mathrm{hr}(\beta$-actin/10\% CS).

1989) is blocked by IFN- $\gamma$. Similarly, in human colon cancer cells, interferons block insulin-stimulated growth (Hamburger et al., 1988). We hypothesized that IFN- $\gamma$ would arrest neuronal growth by distupting expression of the endogenously produced mitogenic growth factor IGF-II, or its receptors.

We tested this hypothesis using the SH-SY5Y human neuroblastoma cell line (Biedler et al., 1978), which expresses IGF-II mRNA and IGF receptors (Martin et al., 1992). The utility of SH-SY5Y cells for studying neuronal development and differentiation is well documented (for review, see Påhlman et al, 1990). The SHSY5Y cell line synthesizes a number of neuron-specific proteins, including neurofilaments, noradrenergic, and catecholaminergic neurotransmitters, cholinergic receptors, the growth cone associated protein GAP-43, and neuron-specific enolase (Påhlman et al., 1990). Morphological and biochemical differentiation of SH-SY5Y cells, characterized in part by increased neurite formation and elevated levels of noradrenalin and neuron-specific enolase, can be induced by retinoic acid and the phorbol ester 12-O-tetradecanoyl-phorbol-13-acetate (Påhlman et al., 1984).

We report that low doses of IFN- $\gamma(20-100 \mathrm{U} / \mathrm{ml})$ significantly inhibited DNA synthesis as measured by $\left[{ }^{3} \mathrm{H}\right] \mathrm{TdR}$ incorporation in SH-SY5Y neuroblastoma cells, both in the presence and absence of serum. Our observation that a 1-day exposure to IFN- $\gamma$ inhibited DNA synthesis is consistent with an earlier finding in fibroblasts that brief $(18 \mathrm{hr})$ incubations in low doses (10 $\mathrm{U} / \mathrm{ml}$ ) of IFN- $\gamma$ significantly reduce DNA synthesis (Rubin and Gupta, 1980). Moreover, our results demonstrate 

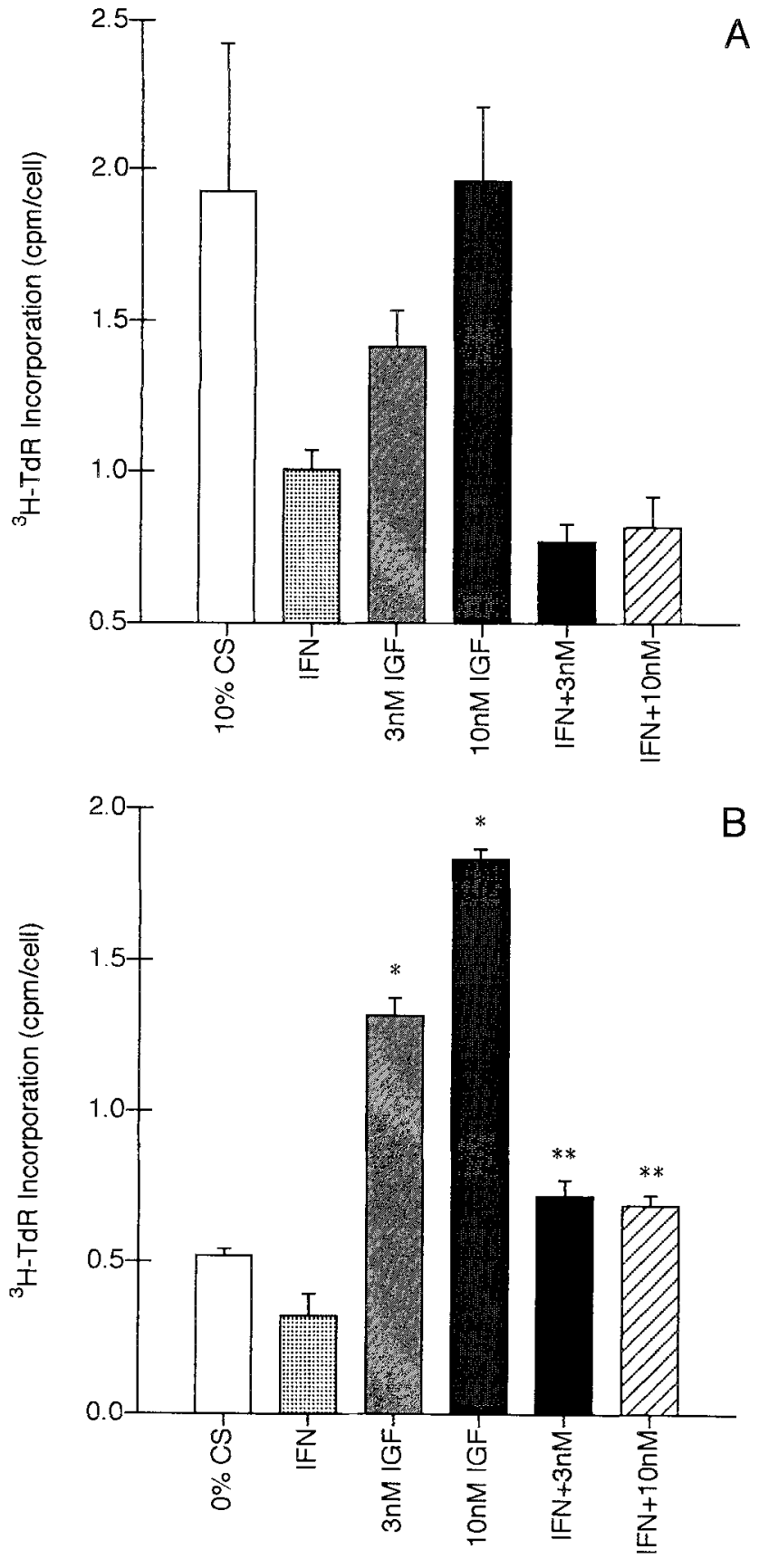

Fig. 7. Effects of IGF-II and IFN- $\gamma$ on $\left[{ }^{3} \mathrm{H}\right] \mathrm{TdR}$ incorporation in SH-SY5Y cells in media supplemented with serum (A) or serum-free media $(B) .\left[{ }^{3} \mathrm{H}\right] \mathrm{TdR}$ incorporation and cell number were measured in parallel wells after a 24-hr exposure to DME (B) $+10 \% \mathrm{CS}(\mathbf{A}) \pm$ IFN- $\gamma(100 \mathrm{U} / \mathrm{ml}) \pm$ IGF-II $(3-10 \mathrm{nM})$, as indicated on the $x$-axis. Values expressed as cpm per cell are means of duplicate wells \pm SEM from a representative experiment performed twice. $* P<0.05$ compared to $0 \%$ CS or $10 \%$ CS control, $* * P<0.05$ compared to IFN- $\gamma$ alone by unpaired, two-tailed $t$ test.
A

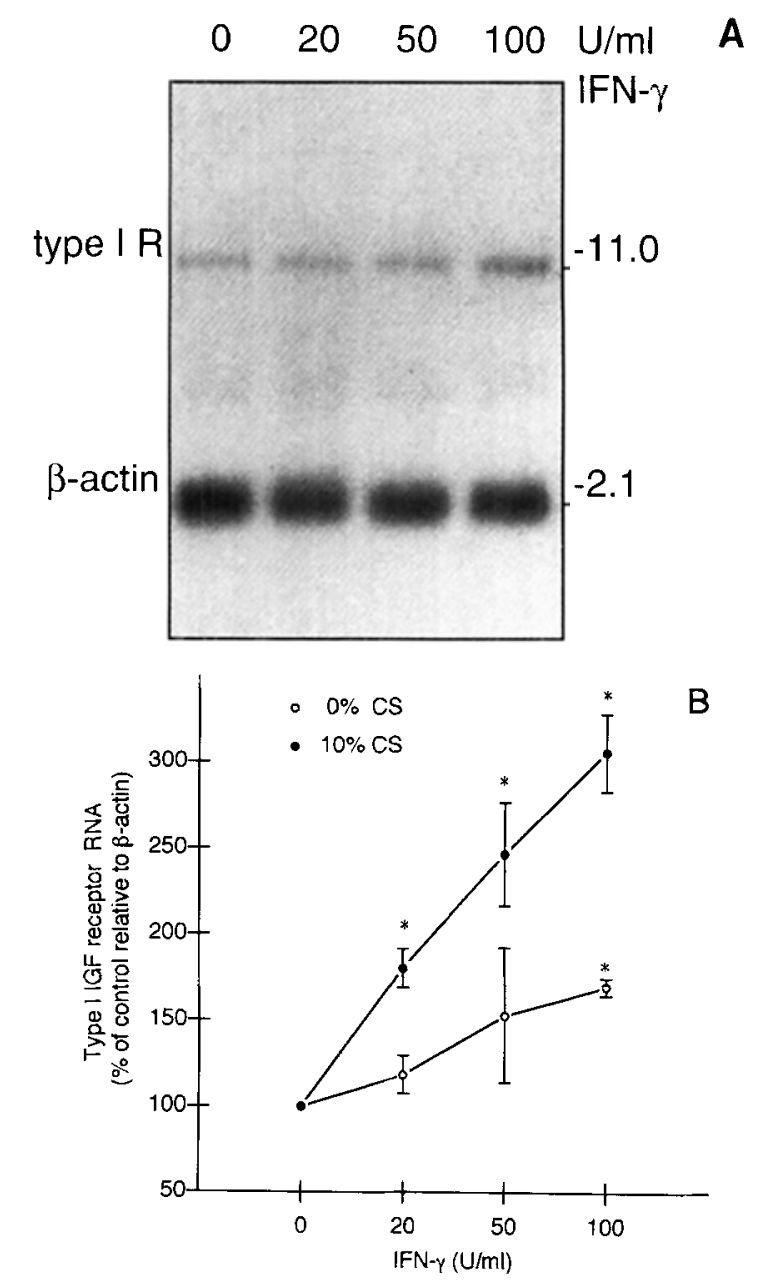

Fig. 8. Northern analysis of type I IGF receptor mRNA. SHSY5Y cells were incubated for three days in DME + 10\% CS $+\operatorname{IFN}-\gamma(0,20,50$, or $100 \mathrm{U} / \mathrm{ml})$ and total RNA isolated. RNA (20 $\mu \mathrm{g}$ per lane) was loaded onto agarose gels as described in Figure 5, and successively hybridized with ${ }^{32} \mathrm{P}-\mathrm{la}-$ beled cDNA probes for type I IGF receptor and $\beta$-actin, as indicated in (A). Amount of IFN- $\gamma$ in $U / \mathrm{ml}$ is indicated above each lane. mRNA transcript sizes are shown at the right of each autoradiogram in $\mathrm{kb}$. Autoradiographs exposed 4 days (type I receptor) and $24 \mathrm{hr}$ ( $\beta$-actin). Densitometric analysis in (B) shows type I IGF receptor mRNA after IFN- $\boldsymbol{\gamma}$ with $(\bullet)$ and without (O) $10 \% \mathrm{CS}$. Autoradiographs from multiple exposures of the experiment from (A) and an additional experiment were quantitated as described in Figure 6. Values are means \pm SEM relative OD expressed as a percentage of the control $(0 \mathrm{U} / \mathrm{ml})$ 11 -kb type I IGF receptor mRNA transcript divided by $\beta$-actin. $* P<0.05$ compared to the $(0 \mathrm{U} / \mathrm{ml})$ control by unpaired, twotailed $t$ test. 


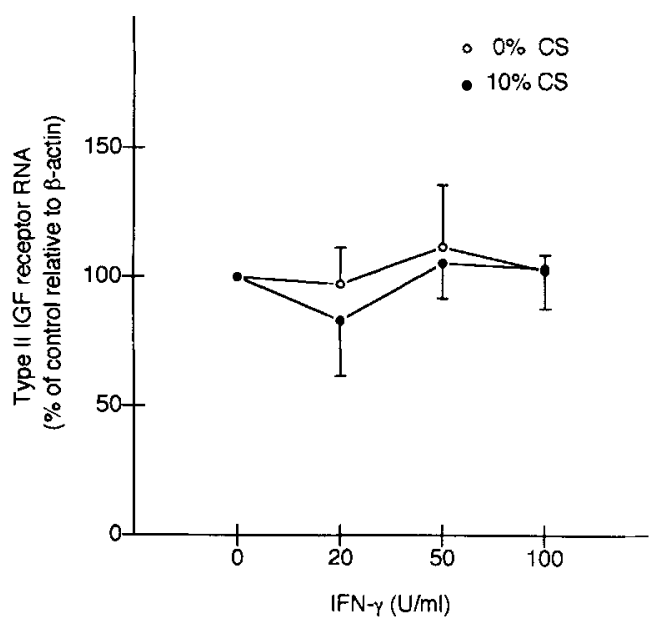

Fig. 9. Densitometric analysis of type II IGF receptor mRNA. SH-SY5Y cells were treated for 3 days in DME $(0)+10 \%$ CS $(\bullet)+\operatorname{IFN}-\gamma(0,20,50$, or $100 \mathrm{U} / \mathrm{ml})$ and Northern analysis was performed as described for Figure 8 . Membranes were successively hybridized with ${ }^{32} \mathrm{P}$-labeled cDNA probes for type II IGF receptor and $\beta$-actin. Autoradiographs from multiple exposures in two experiments were quantitated as described in Figure 6 . Values are means \pm SEM expressed as a percentage of control relative OD of the 9.4-kb type II IGF transcript, divided by the relative OD of $\beta$-actin.

that neuroblastoma cell DNA synthesis is sensitive to IFN- $\gamma$ sooner than the 6-day treatment shown to inhibit DNA synthesis in Lan-1 neuroblastoma cells (Parodi et al., 1989). Previous studies have demonstrated the role of IFN- $\gamma$ as a DNA synthesis blocker in a variety of other normal and malignant cell types, including fibroblasts (Balkwill and Taylor-Papadimitriou, 1978), smooth muscle cells (Warner et al., 1989), mesangial cells (Kakizaki et al., 1991), and colon cancer cells (Hamburger et al., 1988).

The mechanism of growth inhibition by IFN- $\gamma$ is thought to invclve disruption of the cell cycle (Shearer and Taylor-Papadimitriou, 1987). IFN- $\gamma$ decreases the transition rate of cells from $G_{0} G_{1}$ into $S$ phase and prolongs the time cells remain in $S$ (Balkwill and Bokhon'ko, 1984; Creasey et al., 1980). Thus, IFN- $\gamma$ inhibition of DNA synthesis in serum-stimulated $\mathrm{SH}-$ SY5Y cells may be secondary to a block and/or decreased transition time of the cell cycle in $\mathrm{G}_{0} \mathrm{G}_{1}$. Perturbation of $G_{0} G_{1}$ alone, or in combination with lengthening of $S$, would also account for the reduction in SH-SY5Y cell number which occurred after 2 days in IFN- $\gamma$ and serum. We observed no cytotoxic effects of IFN- $\gamma$ on SH-SY5Y cells at doses which inhibited cell growth. This compares favorably to previous work showing IFN- $\gamma$ treatment at doses as high as $700 \mathrm{U} / \mathrm{ml}$ and for exposure times as long as 7 days had no toxic effects on cultured cells (Tyring et al., 1982; Balkwill and Bokhon'ko, 1984). We previously reported that SHSY5Y cells synthesize DNA but do not proliferate under serum free conditions (Martin and Feldman, 1992). In the current study, IFN- $\boldsymbol{\gamma}$ treatment of serum-deprived cells inhibited DNA synthesis, again implying a block at $\mathrm{G}_{0} \mathrm{G}_{1}$. The lack of IFN- $\gamma$ effects on SH-SY5Y cell number was expected (given these cells do not divide in serum-free media), supporting a cytostatic, not cytotoxic, mechanism of IFN- $\gamma$ action (Shearer and TaylorPapadimitriou, 1987).

The inhibitory effects of IFN- $\gamma$ on DNA synthesis and cell number imply disruption of the SH-SY5Y cell cycle. Indeed, interferons have been shown to alter the effects of peptides which control progression through $\mathrm{G}_{0} \mathrm{G}_{1}$ and $\mathrm{S}$. For example, interferon treatment blocks the ability of PDGF, EGF, or FGF to stimulate passage of quiescent fibroblasts through $\mathrm{G}_{0} \mathrm{G}_{1}+\mathrm{S}$ (Howang, 1988; Heyns et al., 1985; Oleszak, 1988). The extent to which interferon inhibits mitogenic activity decreases in the presence of increasing numbers of mitogenic growth factors (Taylor-Papadimitriou, 1983). Since the insulin family of mitogenic growth factors specifically stimulates entry of neuroblasts into $\mathrm{S}$ phase (DiCicco-Bloom and Black, 1988), we speculated that IFN- $\gamma$ could reduce neuroblastoma growth by interfering with the autocrine actions of IGF-II. Previous studies have shown that SHSY5Y cells express mRNA for IGF-II and IGF receptors (Martin et al., 1992) as well as functional IGF-II binding sites (Mattsson et al., 1990; Recio-Pinto and Ishii, 1988), leading to the proposed autocrine role for IGF-II in mediating SH-SY5Y cellular growth or survival. Our finding that SH-SY5Y cells also synthesize and secrete immunoreactive IGF-II further supports this hypothesis. DNA synthesis in serum-deprived SH-SY5Y cells could result from stimulation by endogenously produced and secreted IGF-II. In this way, SH-SY5Y neuroblastoma cells may use IGF-II as an autocrine mitogenic growth or survival factor similar to its role in other neuroblastoma cells (El-Badry et al., 1989). We speculated that IFN- $\gamma$ effects on cell growth are mediated by changes in IGF-II production. By RIA of SH-SY5Y conditioned media, we observed a decrease in immunoreactive IGF-II protein after IFN- $\gamma$ treatment, under conditions where cell number did not change. Therefore, the decrease in immunoreactive IGF-II observed after IFN- $\gamma$ treatment is not explained by a decrease in cell number. Decreased IGF-II protein has also been observed in the liver during other conditions of growth inhibition, i.e., after dexamethasone treatment (Levinovitz and Norstedt, 1989) or fasting (Straus et al., 1991), and in muscle cells after differentiation by basic FGF (Rosenthal et al., 1991).

To determine whether IFN- $\gamma$ inhibition of IGF-II expression also occurred at the mRNA level, we per- 
formed Northern analysis on RNA from SH-SY5Y cells treated with and without IFN- $\gamma$. We found that IFN- $\gamma$ significantly reduces steady-state levels of the $6.0-\mathrm{kb}$ IGF-II mRNA transcript, in the presence or absence of serum. Decreased levels of the 6.0-kb IGF-II mRNA after IFN- $\gamma$ treatment could reflect a decrease in the rate of DNA transcription into RNA or a decrease in IGF-II mRNA stability. The $6.0-\mathrm{kb}$ IGF-II mRNA transcript is one of six $(5.3,5.0,6.0,2.2,4.8,1.8 \mathrm{~kb})$ mRNAs transcribed from the nine exons of the human IGF-II gene (Jansen et al., 1990). The 6.0-kb IGF-II mRNA transcript is produced by activity at the $\mathrm{P} 3$ promoter, one of four (P1-P4) active IGF-II gene promoters (Sussenbach et al., 1991). Activity at these promoters is regulated by tissue and development-specific events, P3 being the most active and producing the $6.0-\mathrm{kb}$ transcript as the major human IGF-II mRNA (Jansen et al., 1990). We also detected the $4.8-\mathrm{kb}$ and $1.8-\mathrm{kb}$ IGF-II mRNA transcripts in SH-SY5Y cells, albeit at much lower levels than the $6.0-\mathrm{kb}$ IGF-II mRNA transcript. There is some controversy over whether the $4.8-\mathrm{kb}$ human IGF-II mRNA transcript derives from promoter P4 (Jansen et al., 1990) or arises form cross-hybridization with rRNA (Irminger et al., 1987); however, this transcript is present in fetal tissues by Northern analysis of poly (A) ${ }^{+}$RNA (Sandberg et al., 1988). The $1.8-\mathrm{kb}$ IGF-II mRNA transcript is thought to arise from cleavage of larger mRNAs, and may regulate total IGF-II mRNA content (Sussenbach et al., 1991).

Our finding that IFN- $\gamma$ down-regulated IGF-II mRNA indicates that the mechanism of interferon growth inhibition may include not only interference with the mitogenic activity of certain growth factors (Oleszak, 1988; Howang, 1988; Heyns et al., 1985), but also regulation of endogenous growth factor production. IFN-y could interfere with positive regulators of IGF-II mRNA, including ACTH, which stimulates IGF-II mRNA in primary human adrenal cells (Voutilainen and Miller, 1987) or growth hormone, which up-regulates IGF-II mRNA in hypophysectomized rat brain (Hynes et al., 1987). Substances other than IFN- $\gamma$ which are known to inhibit IGF-II mRNA expression include basic FGF, which decreases IGF-II mRNA during differentiation of mouse muscle cells (Rosenthal et al., 1991) and the androgen steroid dihydrotestosterone, which decreases IGF-II mRNA production with growth inhibition in neonatal rat liver (Martinoli and Pelletier, 1991).

IFN- $\gamma$ inhibited IGF-II expression and DNA synthesis under similar experimental conditions, suggesting to us there may be a causal relationship between these two events. We were interested, therefore, in determining whether exogenous addition of IGF-II could prevent IFN- $\gamma$ inhibition of DNA synthesis. Previous experiments showed that IGF-II $(0.4-40 \mathrm{nM})$ stimulates total $\left[{ }^{3} \mathrm{H}\right] \mathrm{TdR}$ incorporation in SH-SY5Y cells by $50 \%$ after a 24-hr incubation (Mattsson et al., 1986), similar to its effects in cultured fetal neuroblasts (DiCicco-Bloom and Black, 1988; Lenoir and Honegger, 1983). We observed a much greater (2- to 3-fold) increase in DNA synthesis after a 24-hr treatment with IGF-II, but only in serumfree media. Addition of IGF-II also prevented IFN- $\gamma$ inhibition of DNA synthesis in the absence of serum. However, in the presence of serum, IGF-II did not significantly alter the decrease in DNA synthesis induced by IFN- $\gamma$. These results imply that excess addition of IGF-II can overcome the cytostatic effects of IFN- $\gamma$, but only in the absence of serum. In serum, there is a family of binding proteins with higher affinity for the IGFs than for the IGF receptors. Designated IGF-BPs, these proteins regulate the cellular distribution of IGFs and the binding of IGFs to IGF receptors (Clemmons, 1991). IGF-II added to serum-deprived cells is more likely to interact with IGF receptors, whereas IGF-II added to serum stimulated cells has a higher probability of interacting with IGF-BPs present in serum. Thus, IGF-II may exhibit increased bioavailability for SH-SY5Y cells under conditions of serum deprivation, which would explain its ability to prevent IFN- $\gamma$ inhibition of DNA synthesis.

Differentiation of neural crest-derived cells occurs at a time in development when cells cease to divide (Sauer, 1935). IFN- $\gamma$ inhibition of cell growth may therefore indicate a differentiation pathway in SH-SY5Y cells. We observed that low doses of IFN- $\gamma(20-100$ $\mathrm{U} / \mathrm{ml}$ ) induced the formation of long varicose neuritic processes in the presence of serum, and enhanced neuritic process formation in serum-free media. These results indicate that IFN- $\gamma$ promotes morphological differentiation of SH-SY5Y cells, as reported in other human neuroblastoma cell lines (Ponzoni et al., 1992; Watanabe et al., 1989; Parodi et al., 1989). The exact mechanisms underlying these phenomena are not known. In human GOTO and KP-N-RT neuroblastoma cells, IFN- $\gamma$ enhancement of differentiation is coupled to suppression of the N-myc gene (Watanabe et al., 1989), suggesting an association between IFN- $\gamma$ growth arrest and loss of oncogene activity. IFN- $\gamma$ treatment of Lan- 1 human neuroblastoma cells reduces expression of neuroblastomaspecific cell surface antigens and increases the expression of Lan-1 neuronal cytoskeletal proteins, including neurofilaments and microtubule associated proteins (Parodi et al., 1989). Further evidence that IFN- $\gamma$ promotes differentiation of SH-SY5Y cells is our finding that type I IGF receptor mRNA content is increased by IFN- $\gamma$. Ota and colleagues have reported a correlation between increased type I IGF receptor mRNA and induction of differentiation by phorbol esters in SH-SY5Y cells (Ota et al., 1989), and there is evidence that IGF-II mitogenicity and binding to the type I IGF receptor are 
modulated during phorbol ester-induced differentiation (Mattsson et al., 1986; Påhlman et al., 1991). Moreover, we observed that incubation of SH-SY5Y cells in IFN- $\gamma$ $(100 \mathrm{U} / \mathrm{ml})$ and serum for 3 days increased the secreted activity of tissue-type plasminogen activator (unpublished observations), an event which occurs in association with differentiation of neuroblastoma cells (Neuman et al., 1989).

In summary, the results of experiments presented here demonstrate that SH-SY5Y cells synthesize immunoreactive IGF-II and other components of an IGF-IImediated autocrine growth or survival mechanism. Similarly, other neuroblastoma cells and some fetal tissues have been shown to use IGF-II as an autocrine growth factor (El-Badry et al., 1989; Rappolee et al., 1992; Minniti et al., 1992). We demonstrated that IGF-II expression is negatively regulated by IFN- $\gamma$, both in the presence and absence of serum. Because exogenous addition of IGF-II prevented the inhibitory effects of IFN- $\gamma$ on DNA synthesis in serum-free media, it is possible that IFN- $\gamma$ interferes with autocrine IGF-II-mediated cellular growth. Further experiments will reveal whether IFN- $\gamma$ also disrupts IGF-II binding to the type I or II IGF receptors, as shown for the antineoplastic agent suramin (Minniti et al., 1992). A better understanding of the mechanism by which IFN- $\gamma$ regulates IGF-II expression may lead to improved treatment therapies for neuroblastoma and early developmental disorders.

\section{ACKNOWLEDGMENTS}

Ann Randolph and Mihir Meghani assisted with experiments. We thank Dr. Kevin Cullen for help with the RIA, Dr. Daniel Goldman for assistance with densitometry, and Dr. Yehoash Raphael for helpful discussions. Drs. Graeme Bell, William Sly, Axel Ullrich, and Don Cleveland provided cDNA probes. DMM was supported by NIH training grant NS 07222-09, ROC by NIMH training grant MH-15794, and ELF by NIH grant NS01380.

\section{REFERENCES}

Balkwill FR, Bokhon'ko AI (1984): Differential effects of pure human alpha and gamma interferons in fibroblast cell growth and the cell cycle. Exp Cell Res 155:190-197.

Balkwill F, Taylor-Papadimitriou J (1978): Interferon affects both $G_{1}$ and $S+G_{2}$ in cells stimulated from quiescence to growth. Nature (London) 274:798-800.

Baskin DG, Wilcox BJ, Figlewicz DP, Dorsa DM (1988): Insulin and insulin-like growth factors in the CNS. Trends Neurosci 11: 107-111.

Bell GI, Merryweather JP, Sanchez-Pescador R, Stempien MM, Priestly L, Scott J, Rall LB (1984): Sequence of a cDNA clone encoding human preproinsulin-like growth factor II. Nature (London) 310:775-777.
Biedler JL, Roffler-Tarlov S, Schachner M, Freedman LS (1978): Multiple neurotransmitter synthesis by human neuroblastoma cell lines and clones. Cancer Res 38:3751-3757.

Blundell TL, Humbel RE (1980): Hormone families: Pancreatic hormones and homologous growth factors. Nature (London) 28 : 781-787.

Bondy C, Werner H, Roberts CT Jr, LeRoith D (1992): Cellular pattern of type-I insulin-like growth factor receptor gene expression during maturation of the rat brain: Comparison with insulin-like growth factors I and II. Neuroscience 46:909923.

Borden EC (1992): Interferons: Pleiotropic cellular modulators. Clin Immunol Immunopathol 62:S18-S24.

Chomczynski P, Sacchi N (1987): Single-step method of RNA isolation by acid guanidinium thiocyanate-phenol-chloroform extraction. Anal Biochem 162:156-159.

Clemmons DR (1991): Insulin-like growth factor binding proteins: Roles in regulating IGF physiology. J Dev Physiol 15:105110.

Cleveland DW, Lopata MA, MacDonald RJ, Cowan NJ, Rutter WJ, Kirschner MW (1980): Number and evolutionary conservation of $\alpha$ - and $\beta$-tubulin and cytoplasmic $\beta$ - and $\gamma$-actin genes using specific cloned cDNA probes. Cell 20:95-105.

Creasey AA, Bartholomew JC, Merigan TC (1980): Role of $\mathrm{G}_{0}-\mathrm{G}_{1}$ arrest in the inhibition of tumor cell growth by interferon. Proc Natl Acad Sci USA 77:1471-1475.

Cullen KJ, Smith HS, Hill S, Rosen N, Lippman ME (1991): Growth factor messenger RNA expression by human breast fibroblasts from benign and malignant lesions. Cancer Res 51:49784985.

DiCicco-Bloom E, Black IB (1988): Insulin growth factors regulate the mitotic cycle in cultured rat sympathetic neuroblasts. Proc Natl Acad Sci USA 85:4066-4070.

Drago J, Murphy M, Carroll SM, Harvey RP, Bartlett PF (1991): Fibroblast growth factor-mediated proliferation of central nervous system precursors depends on endogenous production of insulin-like growth factor I. Proc Natl Acad Sci USA 88:21992203.

El-Badry OM, Romanus JA, Helman LJ, Cooper MJ, Rechler MM, Israel MA (1989): Autonomous growth of a human neuroblastoma cell line is mediated by insulin-like growth factor II. J Clin Invest 84:829-839.

Enberg G, Hall K (1984): Immunoreactive IGF-II in serum of healthy subjects and patients with growth hormone disturbances and uraemia. Acta Endocrinol 107:165-170.

Feldman EL, Randolph AE (1991): Mannose 6-phosphate potentiates insulin-like growth factor II effects in cultured human neuroblastoma cells. Brain Res 562:111-116.

Hamburger AW, Condon ME, O'Donnell K (1988): Inhibition of mitogen stimulated growth of human colon cancer cells by interferon. Br J Cancer 58:147-151.

Heyns Adu P, Eldor A, Vlodavsky I, Kaiser N, Fridman R, Panet A (1985): The antiproliferative effect of interferon and the mitogenic activity of growth factors are independent cell cycle events. Exp Cell Res 161:297-306.

Howang M (1988): Recombinant interferon- $\gamma$ inhibits the mitogenic effect of platelet-derived growth factor at a level distal to the growth factor receptor. J Cell Physiol 134:396-404.

Hynes MA, Van Wyk JJ, Brooks PJ, D'Ercole AJ, Jansen M, Lund PK (1987): Growth hormone dependence of somatomedin-C/ insulin-like growth factor-I and insulin-like growth factor-II messenger ribonucleic acids. Mol Endocrinol 1:233-242.

Irminger J-C, Rosen KM, Humbel RE, Villa-Komaroff L (1987): Tissue-specific expression of insulin-like growth factor II 
mRNAs with distinct $5^{\prime}$ untranslated regions. Proc Natl Acad Sci USA $84: 6330-6334$.

Jansen M, Holthuizen P, van Dijk MA, van Schaik FMA, Van den Brande JL, Sussenbach JS (1990): Structure and expression of the insulin-like growth factor II (IGF-II) gene. In Sara, VR, Hall, $\mathrm{K}$ and Löw, H (eds): "Growth Factors: From Genes to Clinical Application." New York: Raven Press, pp 25-40.

Kakizaki Y, Kraft N, Atkins RC (1991): Differential control of mesangial cell proliferation by interferon-gamma. Clin Exp Immunol 85:157-163.

Lee JE, Pintar J, Efstratiadis A (1990): Pattern of the insulin-like growth factor II gene expression during early mouse embryogenesis. Development 110:151-159.

Lenoir D, Honegger P (1983): Insulin-like growth factor I (IGF I) stimulates DNA synthesis in fetal rat brain cell cultures. Dev Brain Res 7:205-213.

Levinovitz A, Norstedt G (1989): Developmental and steroid hormonal regulation of insulin-like growth factor II expression. Mol Endocrinol 3:797-804.

Lin SL, Kikuchi T, Pledger WJ, Tamm I (1986): Interferon inhibits the establishment of competence in $\mathrm{G}_{0} / \mathrm{S}$-phase transition. Science 233:356-359.

Martin DM, Feldman EL (1992): Insulin-like growth factor II gene expression during neuronal growth and differentiation. Endocrine Soc Abstr 74: 108:78 (abstract).

Martin DM, Yee D, Feldman EL (1991): Gene expression of the insulin-like growth factors and their receptors in cultured human retinal pigment epithelial cells. Mol Brain Res 12:181186.

Martin DM, Yee D, Carlson RO, Feldman EL (1992): Gene expression of the insulin-like growth factors and their receptors in human neuroblastoma cells. Mol Brain Res 15:241-246.

Martinoli MG, Pelletier G (1991): Dihydrotesteosterone (DHT) regulation of insulin-like growth factor II mRNA in neonatal rats. Peptide 12:1267-1271.

Mattsson MEK, Enberg G, Ruusala A, Hall K, Påhlman S (1986): Mitogenic response of human SH-SY5Y neuroblastoma cells to insulin-like growth factor I and II is dependent on the stage of differentiation. J Cell Biol 102:1949-1954.

Mattsson MEK, Hammerling U, Mohall E, Hall K, PåhIman S (1990); Mitogenically uncoupled insulin and IGF-I receptors of differentiated human neuroblastoma cells are functional and mediate ligand-induced signals. Growth Factors 2:251-265.

Minniti CP, Maggi M, Helman LJ (1992): Suramin inhibits the growth of human rhabdomyoscarcoma by interrupting the insulin-like growth factor II autocrine growth loop. Cancer Res 52:1830 1835 .

Morgan DO, Edman JC, Standring DN, Fried VA, Smith MC, Roth RA, Rutter WJ, (1987): Insulin-like growth factor II receptor as a multifunctional binding protein. Nature (London) 329:301307.

Morgan DO, Jarnagin K, Roth RA (1986): Purification and characterization of the receptor for insulin-like growth factor $\mathrm{I}$. Biochemistry 25:5560-5564.

Neuman T, Stephens RW, Salonen E-M, Timmusk T, Vaheri A (1989): Induction of morphological differentiation of human neuroblastoma cells is accompanied by induction of tissue-type plasminogen activator. J Neurosci Res 23:274-281.

Nielsen FC, Wang E, Gammeltoft S (1991): Receptor binding, endocytosis, and mitogenesis of insulin-like growth factors I and II in fetal rat brain neurons. $J$ Neurochem 56:12-21.

Oleszak E (1988): Inhibition of mitogenic activity of PDGF, EGF, and FGF by interferon- $\gamma$. Exp Cell Res 179:575-580.

Oshima A, Nolan CM, Kyle JW, Grubb JH, Sly WS (1988): The human cation-independent mannose 6-phosphate receptor. J Biol Chem 263:2553-2562.

Ota A, Shen-Orr Z, Roberts CT Jr, LeRoith D (1989): TPA-induced neurite formation in a neuroblastoma cell line (SH-SY5Y) is associated with increased IGF-I receptor mRNA and binding. Mol Brain Res 6:69-76.

Påhlman S, Ruusala A, Abrahamsson L, Mattsson MEK, Esscher T (1984): Retinoic acid-induced differentiation of cultured human neuroblastoma cells: a comparison with phorbol ester-induced differentiation. Cell Differentiation 14:135-144.

Påhlman S, Mamaeva S, Meyerson G, Mattsson MEK, Bjelfman C, Örtoft E, Hammerling U (1990): Human neuroblastoma cells in culture: a model for neuronal cell differentiation and function. Acta Physiol Scand Suppl 592:25-37.

Påhlman S, Meyerson G, Lindgren E, Schalling M, Johansson I (1991): Insulin-like growth factor I shifts from promoting cell division to potentiating maturation during neuronal differentiation. Proc Natl Acad Sci USA 88:9994-9998.

Parodi MT, Cornaglia-Ferraris P, Ponzoni M (1989): Effects of $\gamma$-interferon on the growth, morphology, and membrane and cytoskeletal proteins expression of Lan-1 cells. Exp Cell Res $185: 327-341$

Ponzoni M, Casalaro A, Lanciotti M, Giuseppe Montaldo P, Cornaglia-Ferraris P (1992): The combination of gamma-interferon and tumor necrosis factor causes a rapid and extensive differentiation of human neuroblastoma cells. Cancer Res 52:931939

Rappolee DA, Sturm KS, Behrendtsen O, Schultz GA, Pedersen RA, Werb Z (1992): Insulin-like growth factor II acts through an endogenous growth pathway regulated by imprinting in early mouse embryos. Genes and Development 6:939-952.

Recio-Pinto E, Rechler MM, Ishii DN (1986): Effects of insulin, insulin-like growth factor-II, and nerve growth factor on neurite formation and survival in cultured sympathetic and sensory neurons. J Neurosci 6:1211-1219.

Recio-Pinto E, Ishii DN (1988): Insulin and insulinlike growth factor receptors regulating neurite formation in cultured human neuroblastoma cells. J Neurosci Res 19:312-320.

Rosenthal SM, Brown EJ, Brunetti A, Goldfine ID (1991): Fibroblast growth factor inhibits insulin-like growth factor-II (IGF-II) gene expression and increases IGF-I receptor abundance in BC3H-1 muscle cells. Mol Endocrinol 5:678-684.

Roth RA (1988): Structure of the receptor for insulin-like growth factor II: the puzzle amplified. Science 239:1269-1271.

Rozengurt E (1986): Early signals in the mitogenic response. Science 234:161-166

Rubin BY, Gupta SL (1980): Differential efficacies of human type I and type II interferons as antiviral and antiproliferative agents. Proc Natl Acad Sci USA 77:5928-5932.

Sandberg A, Engberg C, Lake M, von Holst H, Sara VR (1988): The expression of insulin-like growth factor I and insulin-like growth factor II genes in the human fetal and adult brain and in glioma. Neurosci Lett 93:114-119.

Sauer FC (1935): Mitosis in the neural tube. J Comp Neurol 62:377405.

Shearer M, Taylor-Papadimitriou J (1987): Regulation of cell growth by interferon. Cancer Metastasis Rev 6:199-221.

Sonnenfeld KH, Ishii DN (1982): Nerve growth factor effects and receptors in cultured human neuroblastoma cell lines. J Neurosci Res 8:375-391.

Steel-Perkins G, Turner J, Edman JC, Hari J, Pierce SB, Stover C, Rutter WJ, Roth RA (1988): Expression and characterization of a functional human insulin-like growth factor I receptor. J Biol Chem 263:11486-11492. 
Straus DS, Ooi GT, Orlowski CC, Rechler MM (1991): Expression of the genes for insulin-like growth factor-I (IGF-I), IGF-II, and IGF-binding proteins- 1 and -2 in fetal rat under conditions of intrauterine growth retardation caused by maternal fasting. Endocrinology 128:518-525.

Sussenbach JS, Steenbergh PH, Jansen E, Meinsma D, van Dijk MA, Holthuizen P, de Moor CH, Jansen M, Van den Brande JL (1991): Structure and post-transcriptional regulation of expression of the human IGF-I and -II genes. In Spencer EM (ed): "Modern Concepts of Insulin-like Growth Factors." New York: Elsevier, pp 639-654.

Svrzic D, Schubert D (1991): Insulin-like growth factor 1 supports embryonic nerve cell survival. Biochem Biophys Res Commun 172:54-60.

Taylor-Papadimitriou, J (1983): The effects of interferon on the growth and function of normal and malignant cells. In Burke DC, Morris AG (eds): "Interferons: From Molecular Biology to Clinical Application." Cambridge: Cambridge University Press, pp 109-147.

Tyring S, Klimpel GR, Fleischmann WR Jr., Baron S (1982): Direct cytolysis by partially purified preparations of immune interferon. Int J Cancer 30:59-64.
Ullrich A, Gray A, Tam AW, Yang-Feng T, Le Bon T, Kathuria S, Chen E, Jacobs S, Francke U, Ramachandran J, Fujita-Yamaguchi Y (1986): Insulin-like growth factor I receptor primary structure: comparison with insulin receptor suggests structural determinants that define functional specificity. EMBO J 5:2503-2512.

Voutilainen R, Miller WL (1987): Coordinate tropic hormone regulation of mRNAs for insulin-like growth factor II and the cholesterol side-chain-cleavage enzyme, P450ssc, in human steroidogenic tissues. Proc Natl Acad Sci USA 84:1590-1594.

Warner SJC, Friedman GB, Libby P (1989): Immune interferon inhibits proliferation and induces 2 '-5'-oligoadenylate synthetase gene expression in human vascular smooth muscle cells. J Clin Invest 83:1174-1182.

Watanabe H, Chisaka T, Higuchi T, Tanaka A, Horii Y, Sugimoto T, Imanishi J (1989): Effect of human interferons on morphological differentiation and suppression of $\mathrm{N}-m y c$ gene expression in human neuroblastoma cells. Jpn J Cancer Res 80:10721076 . 